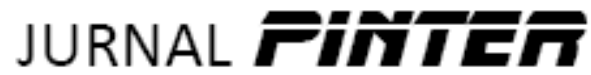 \\ e-ISSN: $2597-4475$ \\ VOL 2. NO.2 DESEMBER 2018 \\ http://doi.org/10.21009/pinter.2.2.7
}

\section{Perbandingan Model Pembelajaran Aktif, Inovatif, Kreatif, Efektif, Menyenangkan Dengan Model Pembelajaran Kooperatif Tipe Team Assisted Individualization Terhadap Hasil Belajar Simulasi Digital Pada Siswa Kelas X SMK Negeri 34 Jakarta}

\author{
Meyvi Lusandi ${ }^{1}$, Ivan Hanafi ${ }^{2}$, Yuliatri Sastrawijaya ${ }^{3}$ \\ 1,2,3 Pendidikan Teknik Informatika dan Komputer Fakultas Teknik \\ Universitas Negeri Jakarta \\ 1'meyvi.lusandi@yahoo.co.id ${ }^{2}$ ihanafi@unj.ac.id, ${ }^{3}$ yuliatri@unj.ac.id
}

\begin{abstract}
ABSTRAK
Penelitian ini bertujuan untuk mengetahui perbedaan model pembelajaran Aktif, Inovatif, Kreatif, Efektif, Menyenangkan (PAIKEM) dengan pembelajaran Kooperatif tipe Team Assisted Individualization (TAI) terhadap hasil belajar siswa pada mata pelajaran Simulasi Digital Kelas X Multimedia dan Kelas X Listrik Di SMKN 34 Jakarta. Penelitian dilakukan di SMKN 34 Jakarta, dilaksanakan pada bulan April - Juni 2016. Penelitian ini menggunakan metode quasy eksperimen, diberikan perlakuan terhadap kedua kelas dengan perlakuan berbeda. Pengambilan sampel menggunakan teknik purposive sampling. Untuk kelas eksperimen diterapkan di kelas X Multimedia menggunakan model pembelajaran PAIKEM dan kelas kontrol diterapkan di kelas X Listrik menggunakan model pembelajaran Kooperatif tipe TAI. Masing-masing kelas terdiri dari 30 siswa. Untuk mendapatkan data penelitian ini dilaksanakan tes awal dan tes akhir untuk mengukur kemampuan kognitif dengan tes pilihan ganda. Hasil penelitian didapatkan siswa yang diterapkan model pembelajaran PAIKEM mendapatkan nilai rata-rata 83,26, sedangkan siswa yang diterapkan model pembelajaran Kooperatif tipe TAI mendapatkan nilai rata-rata 79,04. Sehingga dapat disimpulkan bahwa terdapat perbedaan hasil belajar simulasi digital menggunakan model pembelajaran PAIKEM lebih tinggi dari pada model pembelajaran Kooperatif tipe TAI.
\end{abstract}

Kata Kunci : Model Pembelajaran Aktif, Inovatif. Kreatif, Efektif, Menyenangkan, Model Kooperatif tipe Team Assisted Individualization, Hasil Belajar.

\section{Pendahuluan}

Pendidikan adalah proses pengubahan sikap dan tata laku seseorang atau kelompok orang dalam usaha mendewasakan manusia melalui upaya pengajaran dan pelatihan. Keberhasilan pendidikan yang dicapai oleh suatu bangsa terlihat apabila ada usaha untuk meningkatkan mutu pendidikan bangsa itu sendiri. Oleh karena itu, harus ada kerjasama baik oleh guru kelas maupun guru bidang studi dalam suatu satuan pendidikan.

Dalam proses pendidikan di sekolah, kegiatan belajar merupakan kegiatan pokok yang akan menentukan berhasil dan tidaknya pencapaian tujuan pembelajaran ditentukan oleh bagaimana cara belajar peserta didik baik pada saat ia belajar di sekolah maupun pada saat ia belajar diluar jam sekolah. Hasil belajar yang baik tentu saja berhubungan dengan situasi dan model pembelajaran yang terjadi di kelas. Suasana kelas yang kondusif akan memancing siswa untuk aktif dan semangat dalam belajar, sedangkan suasana kelas yang tidak kondusif akan menurunkan semangat belajar siswa bahkan dapat membuat siswa mengantuk, merasa bosan dan tertidur.

Dari hasil pengamatan yang telah dilakukan saat melaksanakan Praktik Keterampilan Mengajar (PKM) di SMK Negeri 34 Jakarta, masih banyak 
siswa yang mendapatkan hasil belajar kurang maksimal. Hal itu terbukti pada nilai semester ganjil, dari 31 siswa di kelas X Multimedia hanya 5 siswa yang mendapatkan nilai kategori A, 6 siswa mendapatkan nilai kategori B dan 20 Siswa lainnya mendapatkan nilai kategori $\mathrm{C}$.

Salah satu faktor yang mempengaruhi hasil belajar siswa tidak maksimal yaitu seringkali pembelajaran hanya menggunakan model ceramah. Jika model ceramah sering kali digunakan saat proses belajar mengajar hal itu dapat membuat siswa merasa bosan, monoton, dan tidak menarik sehingga cenderung membuat siswa menjadi pasif dan pembelajaran pun menjadi tidak kondusif. Lalu beberapa perilaku ketidakpasifan siswa saat proses pembelajaran di tunjukkan dengan masih banyak siswa yang sering bermain handphone, siswa tidak aktif bertanya, siswa tidak mau mengemukakan pendapat, dan meninggalkan kelas pada saat kegiatan mengajar sedang berlangsung sehingga hasil belajar siswa menjadi kurang maksimal.

Aktifitas belajar yang baik seharusnya melibatkan siswa berinteraksi dengan guru, berani mengemukakan pendapat dan memahami materi yang di sampaikan oleh guru. Untuk menciptakan suasana yang aktif di kelas maka perlu diterapkan pembelajaran yang aktif, efektif, dan menyenangkan. Salah satu nya dengan menggunakan model pembelajaran Aktif, Inovatif, Kreatif, Efektif dan Menyenangkan (PAIKEM) atau model pembelajaran Kooperatif Tipe Team Assisted Individualization (TAI).

Model pembelajaran PAIKEM juga mampu menjadi wadah penyaluran ekspresi, pemikiran, dan pendapat para siswa, khususnya siswa Sekolah Menengah Kejuruan (SMK) yang memiliki psikologis belajar yang bebas, tidak ingin monoton, dan tidak ingin pembelajaran hanya berjalan satu arah yang hanya mendengarkan celoteh guru di depan kelas dan itu dapat disalurkan melalui pembelajaran model PAIKEM. Sedangkan model pembelajran Kooperatif tipe TAI, baik TAI maupun model pembelajaran PAIKEM mampu mendukung praktikpraktik ruangan dikelas, seperti pengelompokan siswa, karena siswa lebih suka dan lebih paham belajar dengan teman sekelompoknya dibandingkan belajar sendiri ataupun mencerna pembicaraan orang dewasa.

Seperti yang dikemukakan oleh Ngalimun Pembelajaran model PAIKEM adalah sebuah pembelajaran yang memungkinkan siswa untuk mengerjakan kegiatan yang beragam dalam rangka mengembangkan keterampilan dan pemahamannya, dengan penekanan siswa belajar sambil bekerja, sementara guru menggunakan berbagai sumber dan alat bantu belajar supaya pembelajaran lebih menarik, menyenangkan dan efektif. Sementara itu siswa dituntut kreatif untuk memperoleh pengetahuan dan berinteraksi dengan sesama teman, guru maupun bahan ajar dengan segala perangkatnya (Ngalimun, 2016: 204).

Dan pembelajaran Kooperatif tipe TAI dapat meminimalisir pengajaran individual yang terbukti kurang efektif . Di SMK Negeri 34 terdapat beberapa siswa mendapatkan nilai yang tinggi sementara adapula siswa yg mendapatkan nilai rendah sehingga model pembelajaran Kooperatif tipe TAI cocok untuk diterapkan saat proses pembelajaran. Pembelajaran Kooperatif tipe TAI disusun secara kelompok dimana siswa dengan kemampuan yang lebih unggul mampu mengajari teman satu kelompoknya yang agak sulit menerima materi pembelajaran. Sehingga keseluruhan hasil belajar siswa di suatu kelas mampu mencapai hasil belajar yang maksimal.

Salah satu langkah yang bisa diambil untuk mengatasi permasalahan diatas terhadap hasil belajar siswa adalah dengan menggunakan model pembelajaran PAIKEM atau model pembelajaran kooperatif tipe TAI. Kedua model pembelajaran ini dirasa cukup cocok untuk diterapkan pada mata pelajaran Simulasi Digital.

Berdasarkan latar belakang masalah tersebut, penulis mengambil judul: "Perbandingan model pembelajaran Aktif, Inovatif, Kreatif, Efektif, Menyenangkan (PAIKEM) dengan model pembelajaran kooperatif tipe Team Assisted Individualization (TAI) terhadapat hasil belajar simulasi digital pada siswa kelas X SMK Negeri 34 di Jakarta".

\section{Dasar Teori}

\subsection{Kajian Teoritis}

2.1.1. Definisi Belajar

Belajar adalah proses perubahan perilaku berkat pengalaman dan latihan. Artinya, tujuan kegiatan adalah perubahan tingkah laku baik yang menyangkut pengetahuan, keterampilan maupun sikap bahkan meliputi segenap aspek organisme atau pribadi (Djamarah dan Zain, 2002: 11). Belajar merupakan suatu proses perubahan yaitu perubahan tingkah laku sebagai hasil dari interaksi dengan lingkungannya dalam memenuhi kebutuhan hidup nya. Perubahan-perubahan tersebut akan nyata dalam seluruh aspek tingkah laku (Slamet, 2010: 2).

\subsubsection{Definisi Hasil Belajar}

Seperti yang dikemukakan oleh Abdurrahman, diacu dalam Jihat (2012: 14) hasil belajar adalah kemampuan-kemampuan yang diperoleh anak setelah melalui kegiatan belajar. Belajar itu sendiri merupakan suatu proses dari seseorang yang berusaha untuk memperoleh suatu 
bentuk perubahan perilaku yang relative menetap. Pendapat yang sama juga dikemukakan oleh Djamarah (2005: 87) bahwa hasil belajar yang diharapkan dimiliki anak didik berupa kemampuankemampuan seperti tersirat dalam tujuan pembelajaran.

\subsubsection{Faktor-Faktor yang Mempengaruhi Hasil Belajar}

Menurut Slameto (2010: 54-69) faktorfaktor yang mempengaruhi hasil belajar adalah sebagai berikut.

a. Faktor internal, ialah faktor yang ada dalam diri individu yang sedang belajar. Faktor internal meliputi faktor jasmaniah, faktor psikologis, faktor kelelahan.

b. Faktor eksternal, ialah faktor yang ada di luar individu. Faktor eksternal meliputi faktor keluarga, faktor sekolah, dan faktor masyarakat.

\subsection{Simulasi Digital}

Mata pelajaran Simulasi Digital adalah mata pelajaran yang membekali siswa agar dapat mengomunikasikan gagasan atau konsep melalui media digital. Dalam proses pembelajaran, siswa dapat mengomunikasikan gagasan atau konsep yang dikemukakan orang lain dan mewujudkannya melalui media digital, dengan tujuan menguasai teknik mengomunikasikan gagasan atau konsep. kemampuan mengomunikasikan gagasan atau konsep dengan tepat, mencerminkan kecerdasan pola pikir dan tingkat penguasaan gagasan atau konsep tersebut.

Media digital yang dimanfaatkan untuk mengomunikasikan gagasan atau konsep, dipilih dari yang telah tersedia secara luas melalui aplikasi atau platform digital dengan menggunakan peralatan elektronika atau peralatan teknologi informatika dan komunikasi yang ada.

Tujuannya, siswa mampu mengomunikasikan gagasan atau konsep yang ditemukannya sendiri atau modifikasi dari gagasan atau konsep yang sudah ada. Hasil akhir simulasi visual adalah data video digital nantinya bisa dilengkapi dengan narasi audio. Simulasi visual bisa menjadi pendukung ilustrasi presentasi video yang akan disampaikan.

\subsection{Model Pembelajaran}

Menurut Wahab (2012: 52) model pembelajaran adalah sebuah perencanaan pengajaran yang menggambarkan proses yang ditempuh pada proses belajar mengajar agar dicapai perubahan spesifik pada perilaku siswa seperti yang diharapkan. Model pembelajaran mengacu pada pendekatan pembelajaran yang akan digunakan, termasuk di dalamnya tujuan-tujuan pengajaran, tahap-tahap dalam kegiatan pembelajaran, lingkungan pembelajaran, dan pengelolaan kelas (Arends, 1997: 7, diacu dalam Trianto, 2007: 1).

2.3.1. Definisi Model Pembelajaran Aktif, Inovatif, Kreatif, Efektif, Menyenangkan (PAIKEM)

Menurut Ngalimun, dkk. (2016: 204-207) model pembelajaran PAIKEM dapat dilihat dalam uraian berikut.

a. Pembelajaran Aktif, adalah pembelajaran yang mengajak peserta didik untuk belajar secara aktif. Ketika peserta didik belajar dengan aktif, berarti mereka yang mendominasi aktivitas dalam pembelajaran. Mereka secara aktif menggunakan otak, baik untuk menemukan ide pokok dari materi pembelajaran, memecahkan persoalan, ataupun mengaplikasikan apa yang baru mereka pelajari, ke dalam satu persoalan yang ada dalam kehidupan nyata.

b. Pembelajaran Inovatif, adalah pembelajaran yang mengembangkan kemampuan peserta didik untuk melahirkan pemikiran atau ide-ide sendiri yang biasanya dapat muncul dari situasi pembelajaran kondusif dan bebas dari perasaan tertekan, takut atau cemas.

c. Pembelajaran Kreatif, adalah pembelajaran yang mampu menciptakan peserta didik lebih aktif, berani menyampaikan pendapat dan berargumen, menyampaikan masalah atau solusinya.

d. Pembelajaran Efektif, pembelajaran efektif berarti model pembelajaran apapun yang dipilih harus menjamin bahwa tujuan pembelajaran akan tercapai secara maksimal.

e. Pembelajaran Menyenangkan, merupakan pembelajaran yang didesain sedemikian rupa sehingga memberikan suasana penuh keceriaan, menyenangkan, dan yang paling utama tidak membosankan peserta didik.

\subsubsection{Definisi Model Pembelajaran Kooperatif Tipe Team Assisted Individualization}

Model pembelajaran Kooperatif tipe Team Assisted Individualization (TAI) merupakan sebuah program pedagogik yang berusaha mengadaptasikan pembelajaran dengan perbedaan individual siswa secara akademik. Pengembangan model pembelajaran tipe TAI dapat mendukung praktikpraktik ruang kelas, seperti pengelompokan siswa, pengelompokan kemampuan di dalam kelas, pengajaran terprogram, dan pengajaran berbasis komputer.

Tujuan pembelajaran kooperatif tipe TAI adalah untuk meminimalisasi pengajaran individual yang terbukti kurang efektif, selain itu juga ditujukan 
untuk meningkatkan pengetahuan, kemampuan, serta motivasi siswa dengan belajar kelompok (Slavin, 1994, diacu dalam Huda, 2014: 200).

\subsection{Kerangka Konseptual}

Salah satu faktor yang mempengaruhi hasil belajar peserta didik adalah model pembelajaran serta peran guru sebagai pengarah dalam pembelajaran di kelas. Pembelajaran Simulasi Digital kelas X MM SMK Negeri 34 Jakarta dikatakan belum optimal, karena pembelajaran masih berjalan satu arah yang berpusat pada guru serta pada saat pembelajaran sedang berlangsung peserta didik kurang dilibatkan dalam proses pembelajaran sehingga peserta didik kurang antusias dan cepat merasa bosan.

Salah satu usaha yang dapat dilakukan yaitu dengan pemilihan model pembelajaran yang sesuai dengan kondisi siswa dimana pembelajaran mampu melibatkan siswa secara langsung untuk aktif dan dapat menunjang keberhasilan belajar. Salah satu model pembelajaran yang dapat diterapkan ialah model PAIKEM.

Model pembelajaran PAIKEM adalah pembelajaran yang memungkinkan peserta didik untuk mengerjakan kegiatan yang beragam dalam rangka mengembangkan keterampilan dan pemahamannya, dengan penekanan peserta didik belajar sambil bekerja, sementara guru menggunakan berbagai sumber dan alat bantu belajar supaya pembelajaran lebih menarik, menyenangkan dan efektif. Sedangkan model pembelajaran Kooperatif tipe TAI adalah siswa ditempatkan dalam kelompokkelompok kecil dan diajarkan bagaimana bekerja sama dalam suatu kelompok yang terdiri atas 4 sampai 6 siswa sehingga siswa yang lemah dapat terbantu dalam menyelesaikan masalah dalam pembelajarannya.

Perbedaan model pembelajaran PAIKEM dengan model pembelajaran TAI dianalisis dari hasil belajar siswa berdasarkan post test. Berdasarkan hasil belajar siswa akan diambil kesimpulan mengenai perbedaan model pembelajaran PAIKEM dengan model pembelajaran Kooperatif tipe TAI.

\subsection{Hipotesis Penelitian}

Berdasarkan uraian teoritis yang telah dikemukakan di atas, maka hipotesis dalam penelitian ini yaitu ada perbedaan antara model pembelajaran Aktif, Inovatif, Kreatif, Efektif, Menyenangkan lebih tinggi dibandingkan dengan model pembelajaran Kooperatif tipe Team Assisted Individualization terhadap hasil belajar pada mata pelajaran Simulasi Digital kelas X di SMK Negeri 34 Jakarta.

\section{Metodologi Penelitian}

\subsection{Tempat, Wakktu dan Subjek Penelitian}

Penelitian ini dilaksanakan di SMK NEGERI 34 Jakarta yang berlokasi di jalan Kramat Raya No.93, Kelurahan Paseban, Kecamatan Senen, 10440. Waktu penelitian ini akan dilaksanakan pada semester genap tahun pelajaran 2015-2016, yaitu pada bulan AprilJuni 2016.

Subjek penelitian ini adalah siswa kelas $\mathrm{X}$ Multimedia dan X Listrik SMK Negeri 34 Jakarta dimana Simulasi Digital dijadikan sebagai mata pelajaran yang akan diteliti.

\subsection{Populasi dan Sampel Penelitian}

3.2.1. Populasi

Populasi adalah wilayah generalisasi yang terdiri dari objek atau subjek yang mempunyai kualitas dan karakteristik tertentu yang ditetapkan oleh peneliti untuk dipelajari dan kemudian ditarik kesimpulannya (Sugiyono, 2011: 90). Populasi dalam penelitian kali ini adalah seluruh siswa kelas $\mathrm{X}$ Multimedia dan X Listrik SMKN 34 di Jakarta dimana total populasinya berjumlah 60 siswa.

\subsubsection{Sampel}

Sampel adalah sebagian individu yang diselidiki dari keseluruhan individu penelitian. Sampel yang baik yaitu sampel yang memiliki populasi atau yang representative artinya yang menggambarkan keadaan populasi atau mencerminkan populasi secara maksimal.Sampel yang digunakan dalam penelitian ini ada dua kelas, yaitu kelas X Multimedia dan X Listrik di SMK Negeri 34 Jakarta, tahun pelajaran 2015/2016 yang masing-masing kelas berisi 30 siswa.

\subsection{Definisi Operasional}

\subsubsection{Penelitian}

Menurut (Sukmadinata, 2010: 5) metode penelitian adalah rancangan yang berisi rumusan tentang objek atau subjek yang akan diteliti, teknikteknik pengumpulan data, prosedur pengumpulan dan analisis data berkenaan dengan fokus dan masalah tertentu. Sedangkan menurut Emzir (2011: 3) penelitian pada dasarnya adalah suatu kegiatan atau proses sistematis untuk memecahkan masalah yang dilakukan dengan menerapkan metode ilmiah.

\subsubsection{Variabel Penelitian}

a. Variabel Bebas

Variabel bebas yaitu kondisi-kondisi atau karakteristik-karakteristik yang oleh peneliti dimanipulasi dalam rangka untuk menerangkan hubungannya dengan fenomena yang diobservasi (Narbuko dan Achmadi, 2009: 119). Variabel bebas dalam penelitian ini adalah model pembelajaran Aktif, Inovatif, Kreatif, efektif, Menyenangkan (PAIKEM) 
dan model pembelajaran Kooperatif tipe Team Asissted Individualization (TAI).

b. Variabel Terikat

Variabel terikat yaitu kondisi atau karakteristik yang berubah atau muncul ketika penelitian mengintroduksi, pengubah atau mengganti variabel bebas (Narbuko dan Achmadi, 2009: 119). Variabel terikat dalam penelitian ini adalah hasil belajar pada mata pelajaran Simulasi Digital.

\subsection{Metode dan Rancangan Penelitian}

\subsubsection{Metode Penelitian}

Metodologi artinya cara melakukan sesuatu dengan menggunakan pikiran secara seksama untuk mencapai suatu tujuan. Dan penelitian adalah suatu kegiatan untuk mencari, mencatat, merumuskan dan menganalisis sampai menyusun laporannya (Narbuko dan Achmadi, 2009: 1). Penelitian ini dilaksanakan menggunakan metode quasy eksperimen.

\subsubsection{Desain Penelitian}

Desain yang digunakan dalam penelitian ini adalah Pre test-Post test Control Group dengan pola pada tabel sebagai berikut. (Sugiyono, 2013: 112 ).

Tabel 3.1. kelompok penelitian

\begin{tabular}{|c|c|c|c|}
\hline Kelompok & Pretest & Perlakuan & Posttest \\
\hline KE & $0_{1}$ & $X_{1}$ & $0_{2}$ \\
\hline KK & $0_{3}$ & $X_{2}$ & $0_{4}$ \\
\hline
\end{tabular}

Keterangan :

$\mathrm{KE} \quad=$ Kelompok Eksperimen

$\mathrm{KK}=$ Kelompok Kontrol

$0_{1}=$ Tes awal yang diberikan untuk kelompok eksperimen dan kelompok kontrol

$0_{3}=$ Tes awal yang diberikan untuk kelompok eksperimen dan kelompok kontrol

$X_{1}=$ Pembelajaran dengan menggunakan model pembelajaran PAIKEM

$X_{2}=$ Pembelajaran dengan menggunakan model pembelajaran kooperatif tipe TAI

$0_{2}=$ Tes akhir yang diberikan untuk kelompok eksperimen dan kelompok kontrol

$0_{4}=$ Tes akhir yang diberikan untuk kelompok eksperimen dan kelompok kontrol

\subsection{Perlakuan Penelitian}

Penelitian ini membutuhkan 2 kelas, yaitu siswa kelas X SMK Negeri 34 Jakarta yang berjumlah masing-masing 30 siswa. Satu kelas yang selanjutnya ditetapkan menjadi kelas eksperimen dan kelas satunya lagi ditetapkan menjadi kelas kontrol. kemudian diberikan rangkaian kegiatan seperti pada tabel di bawah ini :

Tabel 3.2. Perlakuan yang diberikan pada kelompok eksperimen dan kelompok kontrol selama penelitian

\begin{tabular}{|c|c|c|c|}
\hline \multicolumn{2}{|c|}{ Perlakuan } & $\begin{array}{c}\text { Kelompok } \\
\text { Eksperimen (KE) }\end{array}$ & $\begin{array}{c}\text { Kelompok } \\
\text { Kontrol (KK) }\end{array}$ \\
\hline \multirow[t]{3}{*}{ Sama } & 1. Materi & $\begin{array}{l}\text { - Simulasi } \\
\text { Visual } \\
\text { - Aplikasi } \\
\text { pengolah } \\
\text { simulasi visual } \\
\text { tahap pra } \\
\text { produksi }\end{array}$ & $\begin{array}{l}\text { - Simulasi } \\
\text { Visual } \\
\text { - Aplikasi } \\
\text { pengolah } \\
\text { simulasi visual } \\
\text { tahap pra } \\
\text { produksi }\end{array}$ \\
\hline & 2. Waktu & 6 kali pertemuan & 6 kali pertemuan \\
\hline & 3. Desain & Pre test-post test & Pre test-Post test \\
\hline $\begin{array}{l}\text { Tidak } \\
\text { Sama }\end{array}$ & 4. Model & $\begin{array}{l}\text { Model } \\
\text { pembelajaran } \\
\text { Aktif, Inovatif, } \\
\text { Kreatif, Efektif, } \\
\text { Menyenangkan } \\
\text { (PAIKEM) }\end{array}$ & $\begin{array}{l}\text { Model } \\
\text { pembelajaran } \\
\text { Kooperatif tipe } \\
\text { Team Assisted } \\
\text { Individualization }\end{array}$ \\
\hline
\end{tabular}

\subsection{Instrumen Penelitian}

Instrumen yang digunakan dalam penelitian ini adalah soal ujian akhir berbentuk pilihan ganda untuk ranah kognitif. Tes hasil belajar kognitif digunakan untuk mengukur dan menilai penguasaan siswa pada kompetensi yang berkaitan dengan simulasi visual dan aplikasi pengolah simulasi visual tahap pra produksi. Tes hasil belajar kognitif yang disusun pada penelitian ini berupa tes berbentuk pilihan ganda dengan lima pilihan jawaban dan satu jawaban tepat, terdiri atas soal C1 (pengetahuan), soal C2 (pemahaman), dan soal C3 (aplikasi).

Langkah-langkah penyusunan soal uji coba tes hasil belajar kognitif sebagai berikut:

1. Menentukan jumlah butir soal dan alokasi waktu yang disediakan. Jumlah soal yang diujicobakan adalah 39 butir soal pilihan ganda dengan alokasi waktu masing-maasing 120 menit;

2. Menentukan tipe atau bentuk soal;

3. Menentukan komposisi jenjang dari perangkat tes yang diuji cobakan, terdiri dari 39 butir soal pilihan ganda, yaitu aspek pengetahuan (C1), aspek pemahaman (C2) dan aspek aplikasi (C3).

4. Menentukan kisi-kisi soal dan menyusun butirbutir soal;

5. Mengukur CVR (Content Validity Ratio) soal kepada guru ahli;

6. Mengujicobakan soal kepada peserta didik;

7. Menganalisis hasil uji coba, dalam hal validitas, daya beda, tingkat kesukaran dan reliabilitas;

\subsection{Teknik Pengumpulan Data}


Dalam penelitian ini penulis menggunakan tes dalam pengumpulan data.

Tahapan pengumpulan data sebagai berikut.

1. Langkah awal pada tahap pelaksanaan penelitian adalah peneliti melakukan observasi untuk menentukan kelas yang akan dijadikan objek penelitian serta menentukan kelas eksperimen dan kelas kontrol.

2. Memberikan tes awal pada kedua kelompok penelitian menggunakan soal-soal hasil analisis data uji coba instrumen penelitian.

3. Memberikan treatment pada kelas yang akan dijadikan objek penelitian. Perlakuan ini diberikan sebanyak 5 kali pertemuan. dan mencatat suasana dalam kelas pada setiap pembelajaran.

4. Memberikan tes akhir pada kedua kelompok penelitian menggunakan soal-soal yang sama ketika dilakukan tes awal

5. Melakukan analisis data hasil tes awal dan tes akhir kedua kelompok penelitian untuk melihat perbandingan penggunaan model pembelajaran Aktif, Inovatif, Kreatif, Efektif, Menyenangkan dengan model pembelajaran Kooperatif tipe Team Assisted Individualization.

\section{Hasil Penelitian Dan Pembahasan}

\subsection{Deskripsi Data}

Data dari hasil penelitian dideskripsikan untuk memperoleh gambaran tentang karakteristik distribusi skor hasil belajar Simulasi Digital dari kelompok penelitian. Deskripsi terdiri dari skor tertinggi, skor terendah, mean, median, modus dan varians. Deskripsi data disajikan berturut-turut dari hasil belajar siswa pada mata pelajaran Simulasi Digital dengan menggunaan model pembelajaran PAIKEM dan menggunaan model pembelajaran Kooperatif tipe TAI dalam bentuk tabel distribusi frekuensi yang bertujuan untuk pengujian normalitas.

\subsubsection{Hasil Belajar Simulasi Digital Kelas Eksperimen}

Data awal yang digunakan dalam penelitian diperoleh dari nilai hasil pretest. Pretest digunakan untuk mengetahui keseimbangan kemampuan awal dari kelas eksperimen. Skor pretest pada kelas eksperimen sebelum diberikan perlakuan didapat skor maksimum 73 dan skor minimum 57 sehingga diperoleh rentang skor 16, Mean 64,94, Varians 23,16 dan simpangan baku 4,81.

Selanjutnya kelas eksperimen menggunakan model pembelajaran PAIKEM. Untuk mengukur hasil belajar dilaksanakan posttest. Berdasarkan hasil belajar posttest maka didapat hasil skor maksimum 93 dan skor minimum 74 sehingga diperoleh rentang sebesar 19, Mean 83,26, Varians 27,06, dan simpangan baku 5,20 seperti yang ditunjukkan pada Tabel 4.1.

Tabel 4.1. Hasil Belajar Simulasi Digital Kelompok Eksperimen

\begin{tabular}{|c|c|c|}
\hline \multirow{2}{*}{ Deskripsi } & \multicolumn{2}{|c|}{ Nilai } \\
\cline { 2 - 3 } & Pretest & Posttest \\
\hline Skor Maksimum & 73 & 93 \\
\hline Skor Minimum & 57 & 74 \\
\hline Rentang / Range & 16 & 19 \\
\hline Mean & 64,94 & 83,26 \\
\hline Varians & 23,16 & 27,06 \\
\hline Simpangan Baku & 4,81 & 5,20 \\
\hline
\end{tabular}

Data nilai hasil belajar kelas yang diajar dengan pembelajaran eksperimen terdapat dalam tabel 4.2. distribusi frekuensi seperti dibawah ini.

Tabel 4.2. Distribusi Frekuensi Kelompok Eksperimen Pretest

\begin{tabular}{|c|c|c|c|c|c|c|}
\hline NO & Skor & $\boldsymbol{F}$ & $\begin{array}{c}\text { Batas } \\
\text { bawah }\end{array}$ & $\begin{array}{c}\text { Batas } \\
\text { atas }\end{array}$ & $\boldsymbol{F k}$ & $\boldsymbol{F r}$ \\
\hline 1 & $57-59$ & 3 & 56,50 & 59,5 & 3 & $10,0 \%$ \\
\hline 2 & $60-62$ & 5 & 59,50 & 62,5 & 8 & $16,7 \%$ \\
\hline 3 & $63-65$ & 5 & 62,50 & 65,5 & 13 & $16,7 \%$ \\
\hline 4 & $66-68$ & 9 & 65,50 & 68,5 & 22 & $30,0 \%$ \\
\hline 5 & $69-71$ & 4 & 68,50 & 71,5 & 26 & $13,3 \%$ \\
\hline 6 & $72-74$ & 4 & 71,50 & 74,5 & 30 & $13,3 \%$ \\
\hline
\end{tabular}

Berdasarkan tabel 4.2. di atas, dapat dilihat bahwa frekuensi hasil belajar pretest Simulasi Digital kelas eksperimen paling banyak berada dikelas interval ke 4 (66-68) yaitu sebanyak 9 siswa atau sebanyak $30,0 \%$. Sedangkan hasil belajar posttest, tabel 4.3. Distribusi frekuensi dapat dilihat seperti dibawah ini.

Tabel 4.3. Distribusi Frekuensi Kelompok Eksperimen Posttest

\begin{tabular}{|c|c|l|l|c|c|c|}
\hline No & Skor & $\boldsymbol{f}$ & 3atas bawah & & & \\
\hline 1 & $70-74$ & 2 & 69,50 & 74,5 & 2 & $6,7 \%$ \\
\hline 2 & $75-78$ & 4 & 74,50 & 78,5 & 6 & $13,3 \%$ \\
\hline 3 & $79-82$ & 5 & 78,50 & 82,5 & 11 & $16,7 \%$ \\
\hline 4 & $83-86$ & 8 & 82,50 & 86,5 & 19 & $26,7 \%$ \\
\hline 5 & $87-90$ & 9 & 86,50 & 90,5 & 28 & $30,0 \%$ \\
\hline 6 & $91-94$ & 2 & 90,50 & 94,5 & 30 & $6,7 \%$ \\
\hline
\end{tabular}

berdasarkan hasil belajar posttest, di atas, paling banyak berada dikelas interval ke 5 (87-90), yaitu sebanyak 9 siswa atau sebanyak 30,0\%. Data-data tersebut lebih jelas dapat dilihat pada gambar 4.1. dan 4.2. grafik histogram seperti berikut. 


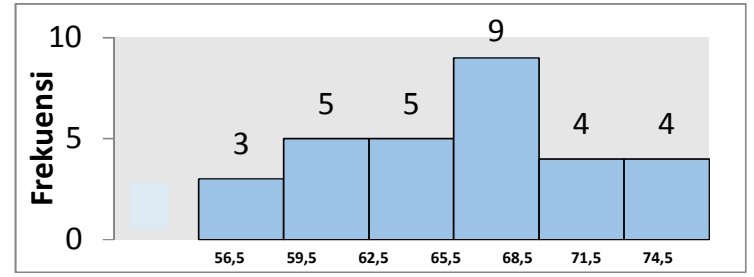

Gambar 4.1. Grafik Histogram Kelompok Eksperimen pretest

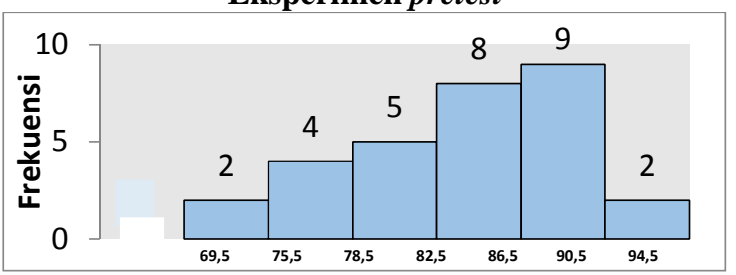

\section{Gambar 4.2. Grafik Histogram Kelompok Eksperimen Posttest}

\subsubsection{Hasil Belajar Simulasi Digital Kelas Kontrol \\ Skor pretest pada kelompok kontrol} sebelum diberikan perlakuan didapat skor maksimum 74 dan skor minimum 57 sehingga diperoleh rentang skor 17, Mean 65,15, Varian 25,08 dan simpangan baku 5,01 .

Dari hasil penelitian berdasarkan hasil belajar posttest didapat hasil belajar siswa adalah, skor maksimum 90 dan skor minimum 67 sehingga diperoleh rentang sebesar 23, Mean 79,04, Varian 28,49, dan simpangan baku 5,34 seperti yang ditunjukkan pada Tabel 4.4.

Tabel 4.4. Deskripsi Hasil Belajar Simulasi Digital Kelompok Kontrol

\begin{tabular}{|c|c|c|}
\hline \multirow{2}{*}{ Deskripsi } & \multicolumn{2}{|c|}{ Nilai } \\
\cline { 2 - 3 } & Pretest & Posttest \\
\hline Skor Maksimum & 74 & 90 \\
\hline Skor Minimum & 57 & 67 \\
\hline Rentang/Range & 17 & 23 \\
\hline Mean & 65,15 & 79,04 \\
\hline Varian & 25,08 & 28,49 \\
\hline Simpangan Baku & 5,01 & 5,34 \\
\hline
\end{tabular}

Data nilai hasil belajar kelas yang diajar dengan pembelajaran kontrol terdapat dalam tabel 4.5. distribusi frekuensi, dapat dilihat seperti di bawah ini.

Tabel 4.5. Distribusi Frekuensi Kelompok Kontrol

\begin{tabular}{|c|c|c|c|c|c|c|}
\multicolumn{7}{c|}{ Pretest } \\
\hline No & skor & $f$ & $\begin{array}{c}\text { Batas } \\
\text { bawah }\end{array}$ & $\begin{array}{c}\text { Batas } \\
\text { atas }\end{array}$ & $f \mathbf{k}$ & $f \mathbf{r}$ \\
\hline 1 & $57-59$ & 3 & 66,5 & 70,5 & 3 & $10,0 \%$ \\
\hline 2 & $60-62$ & 5 & 70,5 & 74,5 & 8 & $16,7 \%$ \\
\hline 3 & $63-65$ & 6 & 74,5 & 78,5 & 14 & $20,0 \%$ \\
\hline 4 & $66-68$ & 9 & 78,5 & 82,5 & 23 & $30,0 \%$ \\
\hline
\end{tabular}

\begin{tabular}{|l|c|c|c|c|c|c|}
\hline 5 & $69-71$ & 4 & 82,5 & 86,5 & 27 & $13,3 \%$ \\
\hline 6 & $72-74$ & 3 & 86,5 & 90,5 & 30 & $10,0 \%$ \\
\hline \multicolumn{2}{|l}{ Jumlah } & 30 & & & & \\
\hline
\end{tabular}

dapat dilihat bahwa frekuensi hasil belajar pretest Simulasi Digital kelas kontrol paling banyak berada dikelas interval ke 4 (66-68) yaitu sebanyak 9 siswa atau sebanyak 30,0 \%. Sedangkan hasil belajar posttest, tabel 4.6. Distribusi frekuensi dapat dilihat seperti berikut.

Tabel 4.6. Distribusi Frekuensi Kelompok

Kontrol Posttest

\begin{tabular}{|c|c|c|c|c|c|c|}
\hline No & Skor & $f$ & $\begin{array}{c}\text { Batas } \\
\text { bawah }\end{array}$ & $\begin{array}{c}\text { Batas } \\
\text { atas }\end{array}$ & $f \mathrm{k}$ & $f \mathbf{r}$ \\
\hline 1 & $67-70$ & 3 & 66,5 & 70,5 & 3 & $10,0 \%$ \\
\hline 2 & $71-74$ & 4 & 70,5 & 74,5 & 7 & $13,3 \%$ \\
\hline 3 & $75-78$ & 6 & 74,5 & 78,5 & 13 & $20,0 \%$ \\
\hline 4 & $79-82$ & 8 & 78,5 & 82,5 & 21 & $26,7 \%$ \\
\hline 5 & $83-86$ & 5 & 82,5 & 86,5 & 26 & $16,7 \%$ \\
\hline 6 & $87-90$ & 4 & 86,5 & 90,5 & 30 & $13,3 \%$ \\
\hline \multicolumn{2}{|c|}{ Jumlah } & 30 & & & & \\
\hline
\end{tabular}

berdasarkan hasil belajar posttest, paling banyak berada dikelas interval ke 4 (79-82), yaitu sebanyak 8 siswa atau sebanyak 26,7\%. Data-data tersebut lebih jelas dilihat pada gambar 4.3. dan 4.4. grafik histogram seperti berikut.

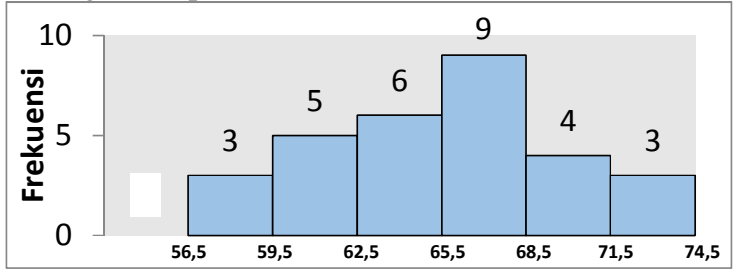

Gambar 4.3. Grafik Histogram Kelas Kontrol Pretest

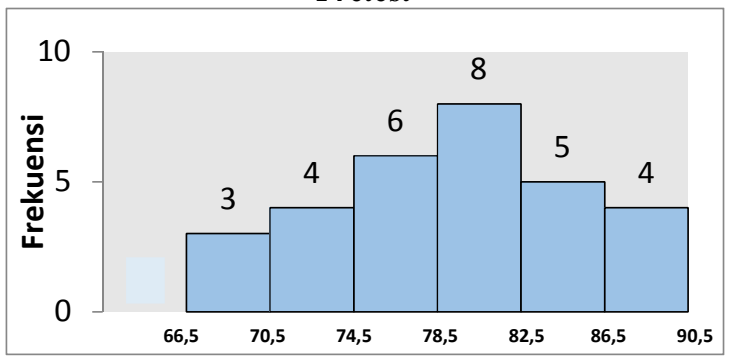

Gambar 4.4. Grafik Histogram Kelas Kontrol Posttest

\subsection{Pengujian Persyaratan Analisis}

\subsubsection{Uji Validitas}

Sebelum peneliti mengadakan kegiatan uji validitas instrument soal tes di SMKN 26 Jakarta, peneliti melakukan pengukuran Content Validity Ratio (CVR) dengan soal 40 butir ke 3 guru yang mengajar mata pelajaran Simulasi Digital. Kemudian hasil CVR yang telah di dapat, ditentukan cocok dan ketidakcocokan antara soal dan indikator dengan ketentuan jika hasil CVR $>0 \rightarrow$ cocok digunakan, jika hasil CVR $<0 \rightarrow$ buang tidak digunakan. 
Berdasarkan hasil uji CVR soal dari 40 butir yang ditentukan cocok dan ketidakcocokan antara soal terdapat 1 soal yang tidak valid yaitu butir soal nomor 6.

Sebelum dilaksanakan perlakuan/treatment di SMKN 34 Jakarta, peneliti mengadakan kegiatan uji validitas instrument soal tes di SMKN 26 Jakarta dengan jumlah responden sebanyak 60 orang siswa. Instrumen ini berbentuk tes yang berupa soal pilihan ganda dengan 5 macam pilihan jawaban. Rumus yang digunakan untuk pengujian validitas adalah dengan cara kolerasi point biseral. Berdasarkan hasil uji validitas instrumen soal, dari 39 butir soal yang diujikan, 35 soal yang valid dan 4 soal yang tidak valid. Butir soal yang valid yaitu: 1, 2, 3, 4, 5, 7, 8, 9, $10,11,12,13,14,15,17,18,19,21,22,23,24,25$, $27,28,29,30,32,33,34,35,36,37,38$, dan 39 sedangkan soal yang tidak valid yaitu : 16, 20, 26 dan 31.

\subsubsection{Uji Reliabilitas}

Setelah melakukan analisis validitas soal, kemudian peneliti menghitung realibilitas terhadap 35 soal tersebut menggunakan rumus KR-20. Berdasarkan uji reabilitas soal, maka diperoleh indeks reabilitas soal yaitu 0,78. Angka tersebut menunjukkan bahwa soal tersebut memiliki reliabilitas/tingkat keajegan yang tinggi karena indeks reliabilitasnya lebih dari 0,7 berdasarkan tabel. Dengan demikian instrumen tes tersebut dinyatakan reliabel.

\subsubsection{Uji Normalitas Data}

Uji normalitas data dengan menggunakan uji liliefors dalam penelitian ini mempunyai kriteria pengujian sebagai berikut:

1. Jika $l_{\text {hit }} \leq l_{\text {tab }}$ terima $H_{0}$

2. $l_{\text {hit }}>l_{\text {tab }}$ tolak $H_{0}$

$l_{\text {hitung }}$ adalah nilai absolut selisih terbesar dari perhitungan Liliefors, dan $l_{\text {tabel }}$ adalah nilai kritis dari tabel Uji Liliefors dengan taraf nyata (taraf signifikan) $=0,05$ atau $5 \%$.

Uji hipotesis atau uji kesimpulan pada uji Normalitas ini didefinisikan sebagai berikut :

1. $H_{0}$ : data hasil belajar siswa berasal dari populasi yang berdistribusi normal

2. $H_{1}$ : data hasil belajar siswa berasal dari populasi yang berdistribusi tidak normal.

Berdasarkan data nilai pretest kedua kelompok, seperti ditujukan pada Tabel 4.7. pada kelompok eksperimen didapatkan nilai $l_{\text {hit }}$ sebesar 0,122 dan pada kelompok kontrol nilai $l_{\text {hit }}$ sebesar 0,129 , kemudian $l_{\text {hit }}$ dibandingkan dengan nilai $l_{t a b}(0,161)$ pada taraf signifikan $\alpha=0,05$. Dengan demikian, nilai $l_{\text {hit }}<l_{\text {tab }}$ dapat disimpulkan adalah bahwa kedua data tersebut berasal dari populasi berdistribusi normal $H_{0}$ diterima.
Tabel 4.7. Hasil Uji Normalitas dengan Lilliefors Kelompok Eksperimen dan Kelompok Kontrol Pretest

\begin{tabular}{|c|l|c|c|c|c|}
\hline Uji normalitas & $\mathbf{N}$ & $\alpha$ & $\boldsymbol{l}_{\text {hitung }}$ & $\boldsymbol{l}_{\text {tabel }}$ & Kesimpulan \\
\hline $\begin{array}{c}\text { Kelompok } \\
\text { eksperimen }\end{array}$ & 30 & 0,05 & 0,122 & 0,161 & Normal \\
\hline Kelompok kontrol & 30 & 0,05 & 0,129 & 0,161 & Normal \\
\hline
\end{tabular}

Berdasarkan data nilai tes akhir kedua kelompok, seperti ditujukan pada Tabel 4.8. pada kelompok eksperimen didapatkan nilai $l_{\text {hit }}$ sebesar 0,153 dan pada kelompok kontrol nilai $l_{\text {hit }}$ sebesar 0,133 , kemudian $l_{\text {hit }}$ dibandingkan dengan nilai $l_{t a b}$ $(0,161)$ pada taraf signifikan $\alpha=0,05$. Oleh karena itu, dapat disimpulkan adalah bahwa kedua data tersebut berdistribusi normal $H_{0}$ diterima.

Tabel 4.8. Hasil Uji Normalitas dengan Lilliefors Kelompok Eksperimen dan Kelompok Kontrol Posttest

\begin{tabular}{|c|c|c|c|c|c|}
\hline Uji normalitas & $\mathbf{N}$ & $\alpha$ & $\boldsymbol{l}_{\text {hitung }}$ & $\boldsymbol{l}_{\text {tabel }}$ & Kesimpulan \\
\hline $\begin{array}{c}\text { Kelompok } \\
\text { eksperimen }\end{array}$ & 30 & 0,05 & 0,153 & 0,161 & Normal \\
\hline Kelompok kontrol & 30 & 0,05 & 0,133 & 0,161 & Normal \\
\hline
\end{tabular}

\subsubsection{Uji Homogenitas Data}

Uji homogenitas data dengan menggunakan uji fisher dalam penelitian ini mempunyai kriteria pengujian sebagai berikut :

1. Jika Fhitung $\leq$ Ftabel, terima $H_{0}$

2. Jika Fhitung $>$ Ftabel, tolak $H_{0}$

Pada taraf signifikansi $\alpha=0,05$

$\mathrm{F}$ hitung adalah nilai varians dari perhitungan Fisher, dan Ftabel adalah nilai kritis dari tabel Uji Fisher dengan taraf signifikansi $\alpha=0,05$ atau 5\%

Uji hipotesis atau uji kesimpulan pada uji Homogenitas ini didefinisikan sebagai berikut :

1. $H_{0}$ : kedua kelompok data memiliki varians yang sama.

2. $H_{1}$ : kedua kelompok data tidak memiliki varians yang sama

hasil tes awal untuk uji homogenitas terdapat $f_{\text {hitung }}=1,08 \leq f_{\text {tabel }}=2,03$, maka $H_{0}$ diterima dan disimpulkan kedua kelompok data memiliki varian yang sama atau homogen. Hasil perhitungan uji homogenitas dengan uji $f$ berdasarkan hasil tes awal didapatkan nilai sebagai berikut.

Tabel 4.9. Hasil Uji Homogenitas Kelompok

Eksperimen dan Kelompok kontrol pretest

\begin{tabular}{|c|c|c|c|}
\hline Sumber Data & $\boldsymbol{f}_{\text {hitung }}$ & $\boldsymbol{f}_{\text {tabel }}$ & Kesimpulan \\
\hline $\begin{array}{c}\text { Kelompok Eksperimen } \\
\text { dan Kontrol }\end{array}$ & 1,08 & 2,03 & Homogen \\
\hline
\end{tabular}


Berdasarkan Tabel 4.10. hasil tes akhir untuk uji homogenitas terdapat $f_{\text {hitung }}=1,05 \leq f_{\text {tabel }}=2,03$, maka $H_{0}$ diterima dan disimpulkan kedua kelompok data memiliki varian yang sama atau homogen. Hasil perhitungan uji homogenitas dengan uji $f$ berdasarkan hasil tes akhir didapatkan nilai sebagai berikut.

Tabel 4.10. Hasil Uji Homogenitas Kelompok Eksperimen dan Kelompok Kontrol Posttest

\begin{tabular}{|c|c|c|c|}
\hline Sumber Data & $\boldsymbol{f}_{\text {hitung }}$ & $\boldsymbol{f}_{\text {tabel }}$ & Kesimpulan \\
\hline $\begin{array}{c}\text { Kelompok eksperimen dan } \\
\text { Kontrol }\end{array}$ & 1,05 & 2,03 & Homogen \\
\hline
\end{tabular}

\subsection{Pengujian Hipotesis}

Setelah uji persyaratan diatas, didapat dua kelompok berditribusi normal dan homogen, dilanjutkan pengujian hipotesis. Dalam penelitian ini pengujian hipotesis menggunakan uji-t untuk dua kelompok data dari dua kelompok sampel (tidak berpasangan). Hipotesis yang diuji adalah sebagai berikut:

Kriteria pengujian

$$
\begin{aligned}
& H_{0}: \mu_{1}-\mu_{2} \leq O \\
& H_{1}: \mu_{1}-\mu_{2}>O
\end{aligned}
$$

Tolak $H_{0}$ jika $\mathrm{t}_{\text {hitung }}>\mathrm{t}$ tabel, maka perbandingan hasil belajar Simulasi Digital antara yang diajarkan menggunakan model pembelajaran PAIKEM lebih tinggi dibandingan dengan yang diajarkan menggunakan model pembelajaran Kooperatif tipe TAI.

Terima $H_{0}$ Jika $\mathrm{t}$ hitung $\leq \mathrm{t}$ tabel, maka tidak ada perbandingan hasil belajar Simulasi Digital antara yang diajarkan menggunakan model pembelajaran PAIKEM dengan yang diajarkan menggunakan Kooperatif tipe TAI.

Berdasarkan hasil perhitungan dengan uji-t, diperoleh nilai $\mathrm{t}$ hitung sebesar 3,111 dan nilai $t_{\text {tabel }}$ pada taraf signifikansi $\alpha=0,05$ dan $d f=58$ adalah sebesar 1,671. oleh karena itu $t_{\text {hitung }}>t_{\text {tabel }}$ $(3,133>1,671)$, artinya $H_{0}$ ditolak dan hal ini menunjukkan terdapat perbandingan hasil belajar Simulasi Digital yang positif antara kelas eksperimen dan kelas kontrol dimana model pembelajaran PAIKEM sebagai kelas eksperimen memiliki hasil belajar yang lebih tinggi dibandingkan model pembelajaran Kooperatif tipe TAI sebagai kelas kontrol.

$$
\text { Tabel 4.11. Hasil Uji-t }
$$

\begin{tabular}{|c|c|c|c|c|}
\hline $\boldsymbol{d} \boldsymbol{f}$ & $\boldsymbol{\alpha}$ & $\boldsymbol{t}_{\text {hitung }}$ & $\boldsymbol{t}_{\text {tabel }}$ & Kesimpulan \\
\hline 58 & 0,05 & 3,111 & 1,671 & $H_{0}$ ditolak \\
\hline
\end{tabular}

\subsection{Pembahasan Hasil Penelitian}

Sebelum diberikan perlakuan dengan model pembelajaran, peneliti melakukan pengambilan data nilai kemampuan awal (pretest) siswa di sekolah. Rata-rata nilai pretest kelompok kontrol adalah sebesar 64,94 dan kelompok eksperimen sebesar 65,15 setelah masing-masing kelas diberikan perlakukan yang berbeda, maka di lakukan evaluasi hasil belajar (posttest). Hal ini ditunjukkan dari perolehan nilai terendah kelas ekperimen yaitu 74 dan perolehan nilai tertinggi 93 dengan rata-rata 83,26 sedangkan nilai terendah dari kelas kontrol yaitu 67 dan nilai tertinggi 90 dengan rata-rata 79,04.

hasil perhitungan uji normalitas data hasil belajar kelas eksperimen diperoleh harga $l_{\text {hitung }}=$ 0,153 dan $l_{\text {tabel }}=0,161$ sehingga kedua data tersebut $l_{\text {hit }}<l_{\text {tab }}$ diterima pada taraf signifikan $\alpha$ $=0,05$.

Sedangkan, hasil perhitungan data hasil belajar siswa kelas kontrol diperoleh harga $l_{\text {hitung }}=0,133$ dan $l_{\text {tabel }}=0,161$. Sehingga $l_{\text {hit }}<l_{\text {tab }}$ diterima pada taraf signifikan $\alpha=0,05$. Oleh karena itu dapat disimpulkan bahwa data hasil belajar siswa kelas eksperimen dan kelas kontrol berdistribusi normal.

Data hasil perhitungan homogenitas yang diperoleh pada hasil belajar adalah $f_{\text {hitung }}=1,05$ dan $f_{\text {tabel }}$ bertaraf signifikan $0,05=2,03$. Dengan demikian $1,05<2,03$ atau $f_{\text {hitung }}<f_{\text {tabel }}$. Maka, dapat disimpulkan bahwa data hasil belajar penelitian ini adalah homogen.

Dari data hasil perhitungan statistik dengan menggunakan uji-t yang dilakukan terhadap hasil tes akhir antara kelas eksperimen dan kelas kontrol diperoleh $t_{\text {hitung }}$ sebesar 3,111, sedangkan harga $t_{\text {tabel }}$ pada taraf signifikan $\alpha=0,05$ adalah 1,671 dengan demikian hipotesis $H_{0}$ ditolak, sehingga dapat disimpulkan bahwa siswa yang diajarkan menggunakan model pembelajaran PAIKEM memiliki hasil belajar yang lebih tinggi dibanding siswa yang diajarkan dengan menggunakan model TAI.

Hasil dari perhitungan statistik dan teori yang ada, menjelaskan adanya perbedaan hasil belajar siswa antara siswa yang diajar dengan menggunakan model Pembelajaran PAIKEM dengan siswa yang diajar menggunakan model pembelajaran Kooperatif tipe TAI dengan demikian dapat disimpulkan bahwa perbandingan model pembelajaran PAIKEM lebih tinggi dari pada model pembelajaran Kooperatif tipe Kooperatif tipe TAI terhadap hasil belajar siswa kelas 
X MM pada mata pelajaran Simulasi Digital di SMKN 34 Jakarta.

\section{Kesimpulan dan Saran}

\subsection{Kesimpulan}

Hasil perhitungan dengan uji-t, diperoleh nilai $\mathrm{t}$ hitung sebesar 3,111 dan nilai $t_{\text {tabel }}$ pada taraf signifikansi $\alpha=0,05$ dan $d f=58$ adalah sebesar 1,671 , maka $t_{\text {hitung }}>t_{\text {tabel }}(3,111>1,671)$. Hal ini menunjukkan model pembelajaran PAIKEM lebih tinggi dari pada model pembelajaran Kooperatif tipe TAI terhadap hasil belajar Simulasi Digital pada siswa kelas X SMK Negeri 34 di Jakarta. Dengan demikian penelitian ini menyimpulkan hasil belajar di pengaruhi oleh penggunaan model pembelajaran yang tepat yang dapat merangsang siswa untuk ikut aktif dalam kegiatan belajar mengajar.

\subsection{Saran}

Berdasarkan kesimpulan yang telah dikemukakan diatas, maka peneliti dapat memberikan saran sebagai berikut :

1. Hasil penelitian ini menerangkan bahwa hasil belajar siswa yang menggunakan model pembelajaran Aktif, Inovatif, Kreatif, Efektif, Menyenangkan lebih tinggi dari pada model pembelajaran Kooperatif tipe Team Assisted Individualization dapat digunakan sebagai pedoman bagi guru mata pelajaran Simulasi Digital dalam melaksanakan kegiatan pembelajaran di kelas yang disesuaikan dengan materi yang diajarkan.

2. Guru adalah penentu bagi proses keberhasilan pembelajaran yang diraih siswa, guru berperan dalam menciptakan suasana dan proses pembelajaran di kelas, guru pun bertanggung jawab dengan sejauh mana pemahaman konsep yang dapat dipahami oleh siswa. Oleh karena itu guru dituntut untuk kreatif, salah satunya dengan memilih model pembelajaran Aktif, Inovatif, Kreatif, Efektif, Menyenangkan untuk diterapkan dalam pembelajaran. Dan sebelum model pembelajaran PAIKEM dilaksanakan, guru wajib mempersiapkan dan menciptakan suasana belajar yang menarik dan saat pembelajaran sedang berlangsung, guru menggunakan berbagai alat bantu untuk membangkitkan semangat siswa, guru mendorong siswa untuk menemukan caranya sendiri dalam memecahkan suatu masalah.

3. Bagi siswa, saat model pembelajaran Aktif, Inovatif, Kreatif, Efektif, Menyenangkan diterapkan dalam pelajaran Simulasi Digital, sebaiknya sebagai peserta didik harus selalu meningkatkan minat dan motivasi belajar lebih baik lagi, agar mampu mengikuti dan menerima pelajaran dengan baik dari guru, supaya mencapai hasil yang maksimal.

\section{DAFTAR PUSTAKA}

[1] Aunurrahman. 2011. belajar dan pembelajaran. Bandung: Alfabeta.

[2] Abdul Majid. 2011. Perencanaan pembelajaran. Bandung: Remaja Rosdakarya.

[3] Arikunto dan Suharsimi. 2013. Dasar - Dasar Evaluasi Pendikan. Jakarta: Bumi Aksara.

[4] Budiyono. 2004. Statistik Untuk Penelitian. Surakarta: UNS Press.

[5] Djamarah, Syaiful Bahri. 2005. Guru dan Anak Didik dalam Interaksi dukatif. Jakarta: Rineka Cipta.

[6] Fathurrohman, Muhammad. 2015. model model pembelajaran inovatif. Yogyakarta: Ar-Ruzz Media.

[7] Huda, Miftahul. 2014. model-model pengajaran dan pembelajaran. Yogyakarta: Pustaka Pelajar.

[8] Hamdayama Jumanta. 2014. Model dan Metode Pembelajaran Kreatif dan Berkarakter. Bogor: Ghalia Indonesia.

[9] Juliansyah. 2012. Metodologi Penelitian. Jakarta: Kencana.

[10] Muhammad Fauzani, Ngalimun dan Ahmad Salabi. 2016. strategi dan model pembelajaran. Yogyakarta: Aswaja Pressindo.

[11] Mahmud. 2010. Psikologi Pendidikan. Bandung: Pustaka Setia.

[12] Musfiqon. 2012. panduan lengkap metodologi penelitian pendidikan. Jakarta: Prestasi pustakaraya.

[13] Majid, Abdul. 2013. Strategi Pembelajaran. Bandung: Remaja Rosdakarya.

[14] Narbuko, Cholid dan Abu Achmadi. 2009. metodologi penelitian. Jakarta: Bumi Aksara.

[15] Nasution. 2005. Berbagai Dalam Proses Belajar. Jakarta: Bumi Aksara.

[16] Sutikno, M. Sobry. 2014. Metode \& ModelModel Pembelajaran. Lombok: holistica Lombok

[17] Suhenah, A. Suparno. 2000. Membangun Kompetensi Belajar. Jakarta: Direktorat Jendral Pendidikan Tinggi Departemen Pendidikan Nasional.

[18] Sudjana, Nana. 1999. Penilaian Hasil Proses Belajar Mengajar. Bandung: Remaja Rosdakarya.

[19] Syaiful Bahri Djamarah dan Azwan Zain. 2002. strategi belajar mengajar. Jakarta: Rineka Cipta.

[20] Slameto. 2010. belajar dan faktor-faktor yang mempengaruhinya. Jakarta: Rineka Cipta.

[21] Sugiyono. 2014. metode penelitian kuantitatif kualitatif dan $R \& D$. Bandung: Alfabeta 
[22] Sugiyono. 2012. metode penelitian kuantitatif kualitatif dan R\&D. Bandung: Alfabeta.

[23] Sugiyono. 2011. Metode Penelitian Administrasi. Bandung: Alfabeta.

[24] Trianto. 2007 . model pembelajaran terpadu dalam teori dan praktek. Jakarta: Prestasi Pustaka.

[25] Trianto. 2009. Model Pembelajaran Tematik. Jakarta: Prestasi Pustakaraya.

[26] Wahab Abdul Aziz. 2012. Metode dan ModelModel Mengajar. Cetakan ke-4. 